\title{
Religious Tolerance in Malaysia: Problems and Challenges
}

\author{
NUR FARHANA ABDUL RAHMAN* \& KHADIJAH MOHD KHAMBALI@HAMBALI ${ }^{1}$
}

\begin{abstract}
Every religion is normally perceived from their own religion to tend toward exclusiveness by claiming that their religion is the only true religion, offering the true revelation and the true way of salvation. This exclusiveness started with desire to know the religious status or truth position among other religions. The question on which religion is the ideal religion and ultimately the truest one has always been raised and debated among people of religions. This polemic can be a seed of many conflicts and disagreements between religions in many parts of the world, including Malaysia as a multi-religious country. This is a preliminary study which attempts to explore issues and challenges pertaining to religious tolerance as practiced in Malaysia. This research is a qualitative research which data are gathered from various sources including books, journals, magazines, newspapers, articles and internet sources related to the topic as well as in depth interview with qualified persons. The data will then be analysed using document analysis method. The result shows that religious tolerance in this country is seen working under various and distinctive understanding. The main challenges to practising religious tolerance in Malaysia emerged from none guidance module to practising religious tolerance especially which stated the limitation and the rule in religious tolerance applicable in Malaysia context and lack of understanding of religious tolerance needed within adherents of religion which cause prejudices against the adherents of religions.
\end{abstract}

Keyword: religions in Malaysia, religious pluralism, religious tolerance, toleration

It is obviously seen that there is a struggle in the claims of religious tolerance in this $21^{\text {st }}$ century $\mathrm{AD}$ which is equivalent to the fourteen year of the Hijrah. Claims are fought among the adherents of religions who are seeking for guidance to live in peace and harmony and also to have a mutual understanding for living together. Claims and struggles in the religious tolerance have been questioned by many either individually or in group and organization. Hence, it has also happened in Malaysia as a country with people of different religions. Dynamics of religious life seem to be promising good advantages but yet still to have some drawbacks. However, it is upon the believers of different religions to set a benchmark in producing a positive outcome or vice versa.

\section{The Concept of Tolerance}

The literal and lexical meaning of tolerance means to bear, to endure or to put up with. Tolerance comes from Latin, tolerantia which means flexibility, softness of the heart, broadmindedness and volunteering (Abdul Halim 2008; Jaffary 2003:77). Abdul Halim (2008) explains that tolerance is equivalent to being positive and appreciating others in the frame of

\footnotetext{
${ }^{1}$ Nur Farhana Abdul Rahman*(Corresponding author), Ph.D. Candidate in Department of 'Aqidah and Islamic Thought, Academy of Islamic Studies Universiti Malaya and Lecturer in Department of Theology and Philosophy, Faculty of Islamic Studies, Universiti Kebangsaan Malaysia, 43600 BANGI, Selangor, Malaysia. Email: hanaalkhafiz@gmail.com; Khadijah Mohd Khambali@Hambali, Ph.D., Assoc. Professor at Department of 'Aqidah and Islamic Thought, Academy of Islamic Studies, Universiti Malaya, KUALA LUMPUR, Malaysia. Email: ijamh@um.edu.my.
} 
providing basic rights as human. There are two main models of tolerance: firstly, passive tolerance which means accepting differences as factual. Secondly there is active tolerance, which means being involved with others in the midst of differences and variations. The outcome of tolerance is living side by side peacefully and accepting variations that exist.

Tamring (2008a: 147) states that tolerance in general refers to the willingness of an individual to establish a relationship and co-exist with another individual of a different cultural and social background. The concept of tolerance explained by social sciences scholars is different according to their respective fields. Tolerance can happen in relationships of political, economic and social nature. Those who practice tolerance are able to accept difficulty and critics, being one true self and the same time sacrificing oneself for others as well as being open and accepting. Tolerance certainly is a reciprocal process between two counterparts. The fact of tolerance is living side by side peacefully and appreciating between variations that existed. It can be said that without tolerance, the people of different affiliation will not enjoy the harmony of living together either as a friend, relative, coupling partner or member in the mix-faith family (Abdul Halim 2008).

Agius \& Ambrosewicz (2003) explain that tolerance is a formula to develop co-existence in a civilized way between sides that are different in terms of faith, belief and view. Tolerance means that every individual or community has the same right; to acknowledge the right of others to have a different opinion, desire and behaviour. Based on the Declaration of Principles on Tolerance announced during the General Conference of UNESCO on October 25 until November 1995, tolerance is defined as follows:

\footnotetext{
... is not merely a matter of recognizing and respecting the beliefs and practices of others but recognizing and respecting themselves, as an individual and as a member of the social or ethnic group or class to which they belong. This is particularly the case with tolerance of racial and sexual differences in which the targets are often individuals as representatives of their particular ethnicity or sex.
}

Tolerance is not only the recognition and respect towards beliefs, but also demands respect for the individuals who belong in the society. In contrary, tolerance as planned by the West is tolerance without borders that gives absolute freedom to human rights. For instance, an individual who wants to practice free sex, then his wish should be given based on tolerance. This culture was almost being followed in Malaysia when represents a coalition of Malaysian NGOs (incl. Malaysian Bar Council, SUARAM, Empower, PT Foundation, United Nations, Amnesty International) and individuals proposed the basis of the 'Program Seksualiti Merdeka 2011' that has been planned to take place on November 2, until November 13, 2011 at The Annexe Gallery, Kuala Lumpur. However, the gathering was banned by Polis Diraja Malaysia (Malaysian Royal Police Force) based on the objection by a majority of the Muslims, as it was considered against the ethical values of the Malaysian society.

Agius \& Ambrosewicz (2003) further elaborate that a person who practices tolerance is a person who does not exert any pressure in order to change the belief of another person, respects an opposing view and is free from prejudice. Tolerance is defined as the willingness of an individual to accept other's rights to be different and respecting without being judgmental. Tolerance contributes to the shaping of human rights, pluralism, democracy and law legislation. Tolerance acknowledges that humans are naturally different in terms of appearance, character, behaviour and they have the right to live peacefully without interruptions of their rights. Learning to be a tolerant individual means the readiness to learn something new in regard to ways of thinking and behaving.

Tolerance is instilled through knowledge, openness, communication and freedom of thought. Tolerance is not only a moral value that every individual should have, but it is also a political requirement. Tolerance is capable of changing the culture of antagonism or animosity to culture of peace and harmony. Tolerance is opposite of intolerance, which can be translated to a negative behaviour and rejects the views and actions of others. Intolerance originates from the belief that one's own actions and way of life is superior or better than others. The negative 
effects of intolerance include oppression, ethnic cleansing, apartheid and genocide that deny the needs and rights of others.

In different point of view, Sahib (2008: 85) describes that the above definition confines tolerance to the domain of religion in a limited sense. The term, tolerance over the years and particularly in recent times, has taken on a wholly new set of meanings. Accordingly, this term, dictated by the demands of modernity, now refers to tolerating all manner of views, beliefs and practices of others that are varyingly and even diametrically opposite to one's own. This new sense of tolerance, according to Abdel-Haleem (2009: 79), "is broadening so fast that there are people now, even in the West, who are worried about the extent of the new spirit of tolerance." Thus they feel that the redefined tolerance not only ask for accommodation of differences, "but often demands acceptance of the beliefs and practices of others."

Sahib (2008: 86) argues that there is a real problem in allowing the statement of "acceptance the beliefs and practices of others". It is because the term "acceptance" means "to consent to take what is offered"; "to view with favour"; "to admit the truth of, i.e. acknowledge." There is no harm in admitting partial truth as partial truth and accommodating it accordingly. However, the difficulty arises when such truth is to be acknowledged as full truth. This may not be tolerated since acceptance of it as truth would mean to acknowledge it as equal to the truth one holds. This is one of the problems that arise from pluralism. Therefore, the concept of tolerance as viewed by the West is different from the Islamic point of view.

The meaning of religious tolerance is also referred to other religions point of views. In Christianity, tolerance either in social or religious claims is also categorized in good manners. The word tolerance has never been written in three versions of Bible especially in the famous Bible King James Version, New King James, American Standard Version, New International Bible and English Standard Version. However, there are few examples of the teachings of Jesus that reflect this tolerance as:

John said to Jesus, 'Teacher saw you dispel Guru by evil spirits. We forbid him because he does not belong to us". Jesus said, "Do not forbid him, for no one who has performed a miracle in my name will soon aggravate me. Anyone who is not against us, would be favourable to us". (The Holy Bible, Mark 9:38-40).

In this case, it indicates that Jesus forbids rejecting those who do not believe. This is because the teachings of Jesus were rejected by the villagers in Samaria. Then, the followers of Jesus told him to do something as teaching, but Jesus refused and moved to another town. In addition, Jesus also interacted with the Samaria woman with a good manner though Jews do not recognize Samaria is part of the Jewish.

For Buddhism, Dharma tolerance is known as data. Tolerance and Buddhism is hard to deny because the teachings of this doctrine necessarily based on good moral character. Hence to achieve the perfect nirvana context, all including a great moral tolerance should be fully in line with the teachings of the Buddha by their teachings Noble Eightfold particularly true teaching in action to avoid the repetition of life in a bad state.

For Sikhism, the act of hating human beings where as at the same worshiping God is totally unaccepted because the religion teaches that to know God is through the relationship among other creature. Sikh define God as love, but love is not just limited to the Sikhs, while excluding others, such as Muslims, Hindus, Jews, or Christians, among others. There are three basic teachings of the Sikh which is getting an honest living, sharing the rewards of living with other people and do both in every moment of life without limitations. In accordance with this doctrine, tolerance of other religions is indeed required and it starts from the commitment of the Sikh religion itself. As is often written in the Sikh scriptures start with three words that God is one, or there is only one God - no Hindu God, Muslim God, Christian God, or any gods but only one God. Tolerance between different religions can only grow from the same basic understanding of them. Teachers declare this concept: "There is only one God the Father of all, and we are all his children" and the same thing also expressed by Guru Nanak who said that "There is no Hindu and no Muslim, So which path should I choose? I just choose to follow God's 
way. Expression relating to the belief of Guru Nanak, said that the truth of God is one step ahead of any religious society and it's better than blaming Hindu or Muslim" (Singh 2003).

For Hinduism, as a religion whose beliefs are different either in terms of divinity and belief, Jayaram (n.d.) and Menski (2007) explained that diversity is indeed become the norm in the Hindu religion. The absence of a specific founder and by which have faith in the divine Trinity, Hinduism hade demonstrated readiness in accepting diversity. For the Hindu, this religion is owned by individuals. This believer can take what is good from other religions such as Buddhism, Islam, Christianity and of its kind to be used together with Hindu beliefs. Although in history shows the tolerance of Hindu religion is not sacred in nature, it is only because of the individual's own claims.

Based on the explanation above, the researcher found that the elements and explanation of religious tolerance in Islam, Christianity, Hinduism, Buddhism and Sikhism thus existed; therefore further research should be extended to identify the area and limitations on tolerance that has been provided by each of these religions to form the religious tolerance in Malaysia.

Islam has its own perspective in defining the concept of tolerance. Jaffary (2003: 78) explains the term "tolerance" in Arabic, which refers to al-tasamuh which defines giving and receiving, and not only hoping for some to give and others to receive. Tolerance is an attitude of openness; to listen to different views of others, and functions two-ways; offering one's view and accepting others, and does not affect the religious beliefs of each other in that shared space. However, this tasamuh does not mean to simply accept to the point that it emotionally pressures someone to accept something that is against the teachings of the religion. Tolerance of Islam towards freedom of religion is based on "firm on principle, tolerance with attitude." Islam proposes its followers to hold on to the principle of truth, without disregarding respect towards non-Muslims.

Khadijah Mohd Khambali @ Hambali (2008: 83) stresses that Islam highly values tasamuh as one of the strengths of Islam. In surah al-Muntahanah 60:8, al-Quran explains that justice and goodwill towards others who are of different convictions is one of the main conditions that brought about tolerance. Tasamuh is closely related to the concept of mahabbah (love) that requires every individual to be broad hearted, rational and professional in a certain matter. Nevertheless, mahabbah has the meaning and approach that is more ideal than tolerance, as tolerance often raises confusion among the society; the question arises who should 'give' and who should 'take'. Due to that, lately there have been certain parties who are bold in challenging the credibility and sublimity of Perlembagaan Persekutuan (National Constitution).

The preliminary discussion points that tolerance is a much-needed universal value in building unity in diversity. The practice of tolerance, when it becomes a culture in the daily interaction between people of different religions is able to produce a society with positive attitude, broad hearted and compassionate. However, Islam only allows for tolerance in matters that do not violate the guidelines and requirements of its teachings. Tolerance in Islam is within a space that clarifies the fact of individual's independence so that his life is civil and ethical. This matter will be clearer when the concept of tolerance is discussed in the framework of religious tolerance and ethnic tolerance, as well as the practices in Malaysia.

\section{Tolerance Issues in Malaysia}

There are various suggestions and attempts that have been carried out in Malaysia, particularly in balancing the rights between religions as well as to foster harmony in order to live together as in the implementation of inter-religious dialogue, guidelines as to establish the places of worship for every religion, the existence of the distribution of residence which is without prejudice to various religions or races with no racism like in the early days of independence and lastly, freedom to choose any religion is given to other religions as well as its presence in which Islam is recognized as the federal religion in Malaysia. All these efforts are aimed at the struggle in implementing the religious tolerance. However, it is observed that many controversial issues 
in religious diversity remains pending due to a lack of resources to make a decision (Yong 2012). Religious tolerance is seen working under the various and distinctive understanding.

Different levels of understanding has resulted in the first two conditions, namely, the presence of the Malaysian society who does not understand that there are religions in Malaysia and the second group in which of those who understands this religion is formed based on the notion of individuality and creating different levels of understanding of the religions in Malaysia. This situation is proven by the existence of religious conflicts; whether by internal conflicts (such as revenge against family members who have changed their religion, insincerity with other people's faiths and of its kind) or by external conflicts (such as incidence of riots, claims through the courts and et cetera) which are still occurred.

Firstly, a group of people who do not understand the religions in Malaysia and thus in turn leads to a lack of understanding about religious tolerance. For example, take a deeper look at the reality of religions in Malaysia where the believers are lacking in understanding on the religions that has existed in Malaysia. Thus, by not understanding the existence of religions in Malaysia, it gives a greater impact on the credibility of a particular law or constitution. In Malaysian context, the discussion on the rights and sensitivity of a religion cannot be separated from the discussion of the legislated law and constitution. As a result, claims will indirectly give an impact on the enactment of law and it increases the difficulty to form a harmonious society in Malaysia. This situation is seen through the presence of conflicts due to the rights and sensitivities of a religion especially from various claims made from time to time, particularly from the non-Muslims who are often not satisfied with the privileges of Islam and Muslims pertaining to all matters involving arguments about the right on religion, the right on worship, family rights and social rights.

As for example, the issue of religious conversion for married couples which involves particularly among two different courts of civil and shariah respectively, like if the husband had converted to Islam, but for his wife neither she had changed the religion nor even filed for divorce in civil court, then the husband who embraces Islam will be responsible to provide alimony to his wife for it is an order upon him based on the civil court. In this case the civil court serves as the court of appeal for cases that have been decided by the shariah court. Consequently, this has caused the husband to be the abused spouse. In addition, this conversion will affect the rights of children for example in the case on the rights of a breast-feeding chid whom his mother remained in the same religion, while his father had converted to Islam, the rights of non-Muslims to visit family members during the festival and/of its kind. Various solutions have been given, but somehow the disagreement and dissatisfaction among families are still occurring as a proof on the family division. In contrast, if each family member is capable to comprehend that these religions bring in good morality then certainly the dispute will not take place.

The confusion of Muslims and non-Muslims alike in regard to the definition of tolerance has led to debates in religious issues. For example, greetings and well-wishes to believers of other religions in certain celebrations have demanded clarifications on religious tolerance (Khadijah 2008: 91). In respective to 1 Malaysia concept, the celebration of every religion is celebrated as a symbol of respect to all Malaysians. However, due to the lack of understanding about the limitations on the concept from the Malaysian community eventually gives various controversies like in the allegation of apostasy and polytheism among Muslims. For example, the issue of wearing Kurta (a traditional dress of the Indian community) by the Prime Minister of Malaysia during Diwali celebration was initially discussed as an offense whereas in India, many Muslim citizens tend to wear these clothes. On the other hand, for instance, there are some people who celebrated a festival which violates the basic laws of a religion as what happened during Christmas Day; which is at the end affirmative to be illegal to Muslims based on several reasons; due to the history of the festival that resolves to be theology in nature.

On this basis, some explains how religious tolerance in Malaysia does not happen in all honesty and reality, but can be considered more of cosmetic in nature. This patch-on harmony may encourage the risk of friction, as it is mostly utilitarian and is not based on pure idealism. In 
other words, the harmony is only surface thin. Even if there is effort for that purpose, it only happens in small groups especially the urban intellect and does not involve all ethnicities, particularly from the rural parts.

Another example, in the Higher Learning Institutions, where the merit system is highly demanding to determine a student whether he/she is eligible to be in a residential college or vice versa, where programmes such as attending several festivals as provided in the list are included to be counted in the merit system. If no official guidance and explanation given, it will generate misunderstandings that might cause a fight or actions that are contradict to the religious claims, particularly among Muslim and non-Muslim students.

This misunderstanding is seen to be the reason for no official guidance on the categorization of either culture or religion respectively. Categorization between religion and culture is mostly done by a believer's own understanding and desire too. Apart from that, it will also create confusion to be arisen among the public (Ernizahura 2012). Thus an official guide is needed to help guide the lawmakers in general and to the legislators on merit assessment in the university in particular so that the guidelines is fair and just with due respect to all religious beliefs.

Another problem would be when there are people whom understand about religion, but this understanding is formed based on different levels of the individual owns perception. This in turn leads to an understanding of religious tolerance that exists in varying degrees. This was shown through the example of the implementation of religious tolerance that is understood subjectively. Most people declare that religious tolerance can only be carried out in the programme and all social activities such as visiting the sick, paying hari raya visit and giving donations due to natural disasters. However, if it is related either to the rights of religious in organizations or the right place of worship, such as working collaboratively in cleaning the houses of worship (mosques, churches, temples and etc.), so it cannot be harmonized with other religions as it solely on the respective religion without having any interruption of other beliefs.

Based on the above explanation, in Malaysian context the understanding of a religion is limited in scope to only one religion (Yong 2012). Although some efforts to build understanding and awareness are being put in order to understand other religions apart from the one embraced, yet it is still small in amounts and needed to be improved for a greater impact on the community. For example, there is no doubt that more effort and academic discussions have been existed among the scholars and religious leaders, in particular through a number of approaches such as in forums to clarify religions understanding, inter-religious dialogue as has been carried out in the organization of inter-religious dialogue through government bodies, NGOs (IKIM, ACCIN, MCCBHS), higher education institutions or closed discussion among religious specialists such as convocation of Religious Leaders/Experts as organized by IKIM (Ernizahura 2012) and also the roundtables conference among the religions committees. These approaches usually receive positive response and worked well within the prescribed limits. Nevertheless, the findings and discussions of dialogue is simply known and hovered by the participants without involving an implementation to the society. This effort has resulted ultimately to provide an understanding of the religious unity to become a discussion of the idea or on theory alone, without implement the practical. Thus, it causes no progression in lucidity between religious beliefs.

\section{Challenge of Religious Tolerance in Malaysia}

From the statement above, it can be concluded that disagreement happens due to the nebulous feelings of other religions. Tolerance is merely a person's self reticence without having mutual promises among the religions devotees. It is due to the lack of understanding on the backgrounds and areas as well as limitations to tolerate which has resulted to be sceptical in tolerance. Even it is not impossible if there are still believers who do not know and recognize the need to tolerate. What linger around are clearly the claims on the feelings of uneasiness in the community of religions in Malaysia. Therefore, it is obviously seen that the existence of 
religions and the need on religious tolerance cannot be well understood, even if it is in different levels of understanding as it is depending on the individual's perceptive of other religions, particularly in accepting the availability and limitations of tolerance to all the religions in Malaysia.

The external factor derived from none guidance module to practice religious tolerance especially which stated the limitation and the rule in religious tolerance applicable in Malaysia context. The challenge in Malaysia is seen by defining the rights of Muslims and non-Muslims (al-dhimmi) that are still indistinct in nature. In the study of Ibrahim Che Noh (2001), these problems become the key factors that hinder the unity of various religious as this will cause the struggle on power as well as violation of rights and laws. For example, issues and problems of conversion or apostasy in Malaysia are closely related to the ambiguity problem of the jurisdiction of the civil and shariah court. The study found that there are enactments of law that are contrary or overlapping between civil and shariah in which for a particular case, a decision was difficult to make. Zuliza Kusrin (1999) and Farahwahida et al. (2008), the ambiguity of laws in Malaysia indirectly becomes the reason of the religious conflict to be happened in Malaysia. Both of these studies are to be given focus therefore, it is suggested that the law needs to be improved particularly in shariah and civil courts so that the issue can be easily resolved without further conflict.

Next obstacle can be seen through the lack of appreciation of the non-Muslims to honour Islam as what was given after the post-colonial period, has resulted difficulties on religious tolerance. This is because without respecting the history in the past, it is impossible for the non-Muslims to accept and understand some of the privileges granted to Islam either by constitutional law or other rights. As a result, various demands from non-Muslims will lead to religious conflicts.

Religions internal factors also contributed to the difficulties in the implementation of religious tolerance. For example, as portrayed by Jaffary (2003) the results on study to all intellectuals, stated that religious tolerance was unable to conduct in Malaysia due to Malay's prejudices against the adherents of religions other than Islam. In fact, the failure of Muslims to understand the idea of universality in Islam had caused to molest the Malays in particular on the Islamic revival in Malaysia as if indirectly rejects the non-Muslims and thus creating a negative feeling on the teachings of Islam among them.

Further aggravated challenges are seen when some people are taking advantage on the present religious conflicts by offering a more aggressive proposal, through the introduction of the teaching and understanding of religious pluralism as an approach to religious tolerance through a more liberal or independent, teachings and beliefs of religious pluralism brings the idea that lead to religions equality solution or in other words, all religions were as truthful and equal (union of religious truth). It is claimed that it will lead to a harmony in life because every religion is no longer entitled to claim by comparison that his/her own religion is truth. Through research and evaluation to those who support in religious pluralism, many scholars in particular and the believer refused, saying that this belief is a threat to the formation of religious harmony in society as though trying to form a new religion. This notion seems to complement among other religions by denying the existing differences between religions. However, it is totally opposed because it involves the denial and modifications on core teachings of a religion or belief.

\section{Increasing Religious Tolerance in Malaysia}

Indeed it cannot be denied that there are a number or examples of tolerance from believers of other religions towards Muslims and vice versa. Without tolerance, the common relationship between Muslims and non-Muslims will complicate the effort in building a harmonious life in Malaysia. This can be proven in the Malaysian context of Muslim majority country. As Khadijah (2008: 86) explains that religious tolerance that has been practiced in Malaysia all this while is based on Article 11(1) of the Malaysian Constitution which states: 
Every person has the right to profess and practice his own religion be subjected to Clause (4) spread his religion. Article 12 (2) states that, every religious group has the right to establish and maintain institutions for children's education in its respective religion; but it is legal for the Federation or the State to establish or administer Islamic institutions or organize or aid in the teachings of Islam or spending of funds as required by that purpose. However it is stressed that, as stated in article 12(3) that no one is allowed to demand or force any individual to follow any teachings of certain religion or celebrate any festivals or activities organized by certain religions apart from his own.

Khadijah (2008: 88) further elaborates that the right to religious freedom as stated by Article 11 of the Constitution has for so long functioned as the pulse of racial unity and harmony in Malaysia. The continuance of the harmony can only be realized if the culture of tolerance is also appreciated by the new generation. This endeavour is not easy due to the challenges that must be overcome for the endurance of religious tolerance in this country. Among the main challenges is the generation gap. Today's generation is the second generation after Malaysia has achieved its independence, and it is in this generation which the spirit of fighting is fading. Therefore it is not surprising that the tie of agreement as being proposed in the 'Social Contract' by the first Prime Minister of Malaysia, Tunku Abdul Rahman that was once agreed among Malay, Chinese and Indian leaders is being questioned as the mutual trust and respect has started to weaken.

The effort towards increasing religious tolerance in Malaysia according to Chandra (2010: 259) should be handled by solving the problem of inter-ethnic communication. This problem comes from ignorance of values, attitudes and customs of others, deteriorates with deep-rooted prejudice between two sides; Muslims and non-Muslims. The problematic situation needs to be resolved by increasing the interaction space for the purpose of building trust, respect and compassion between two sides. According to Tamring (2008b: 131), relationship could be a close or distant depends on opportunities of interaction, not only the characteristics of similarities or differences between them. Hence, the more often interaction takes place in the community, the higher potential for tolerance among them. The role of parents in cultivating universal values and non-communal attitude in the new generation is also important for the purpose of producing a future generation who mingle easily, and is not socially awkward with people of different cultures and able to accommodate oneself easily in a different environment.

Khadijah (2008: 91) suggests that religious tolerance can be increased through a softer approach, by appreciating the similarities and respecting differences that exist within each religion. The old defensive approach, which regards religious issues as sensitive to be discussed must be discarded. The best method is to raise and multiply the forms of religious interaction and without limiting them in dialogue programs between religious figures. It should be expanded to schools and institutions of higher learning, so that prejudice may be curbed and managed at an earlier stage. Here, it demonstrates the importance of learning religious theology which enables a person to determine their conduct and position towards the others and this will determine between the absence and the present of tolerance.

It is undeniable that religious tolerance in Malaysia should be expanded so that all levels of society either in the urban or rural areas may be able to nurture the spirit of tolerance through ties of acquaintance and friendship across religions. The culture of tolerance that has been cultivated from encountering, mixing, associating and co-existing generate amicable relationship not just in form of friendship, but this amicability encourages familiarity which leads to the relationship of brotherhood across religions and ethnicities. Starting from this amicable relationship, a society with the culture of tolerance in all aspects of life can be built together. This kind of relationship can be realized through inter-ethnical relationship without limiting acquaintances and choosing friends or spouses from the same ethnic or selecting based on certain ethnicities only.

The research carried by Tamring (2008a: 150) in Toleransi Etnik Bajau dan Kadazandusun di Sabah (Ethnic Tolerance of Bajau and Kadazandusun in Sabah), shows that 
ethnic tolerance in Sabah is high due the factor of extensive interactions in daily lives which lead to openness in having relationship across religion and ethnicity. High ethnic tolerance is described through the readiness or willingness to have an inter-ethnical relationship and their willingness to relate in other kinds or relations either socially, economically and politically. This demonstrates that tolerance has to go through processes depending on the historical and cultural differences of each society in determining the presence of tolerance.

The practice of ethnic tolerance is the way of co-existence of the Sabah society. Laporan Kajian Toleransi Etnik dan Perpaduan Sosial (Report for Research of Ethnic Tolerance and Social Unity) (2007) states that the general opinion believes Sabah has a high level of tolerance. Even with the complexity of the Sabahan composition, we can see clearly the amicable relationship and harmonious environment, the tolerance and mutual respect between the people, which they maintain as their way of life. Kib (2003) also affirms that the building of a church at the shophouse building and also churches built in Muslims' area, which demonstrates that the culture of tolerance is high among the Sabahan, especially the Muslim natives who can accept the existence of worship houses in their area. Therefore, ethnic tolerance colours the social relationship in Sabah and this practice becomes the starting point of the building of religious tolerance in Sabah.

The construction of religious tolerance in Sabah is cultivated through the practice of ethnic tolerance, which is not only highlighted through inter-religious mixing and the establishment of various worship houses. This phenomenon can be seen from the aspect of coexistence in a multi-faith family. This phenomenon is obvious in the life a new Muslim convert, who practiced mixed marriage, either between ethnicities or religions. The report on marriage registry of Jabatan Hal Ehwal Agama Islam Negeri Sabah (Department of Sabah Islamic Affairs) or JHEAINS states that the first case of mixed marriage reported in Keningau was detected as early as 1944. Moreover, inter-ethnicity mixed marriages practiced earlier on by the Chinese with partners of Sabah natives have been there even before the coming of the colonists, and produced the mixed ethnicity known as 'Sino'. The experience of mixed marriage across religion and ethnicity cultivates the spirit of acceptance towards others and shapes the social convention of being tolerant to the differences element that exists between them.

The phenomenon of mixed marriages that is still taking place until now displays a positive development, where unwanted incidents have not yet occurred that negatively affected religious harmony in Sabah. As a result of mixed marriages that involve conversions, the structure of mixed faith family has also becomes a norm in Sabah. In fact, this practice has also produced individuals from the new Muslim converts who live with non-Muslim families. The presences of new Muslim, who are of different faith, are not considered strange in the space of multi-faith family. This is because this practice is accepted as ancestral heritage that has been going on for a very long time and the process civilizing this practice is still very much alive.

The mix-faith family does not only involve members of different faith, but also displays different religious practices. This matter has often resulted in misconception and anxiety in a family where its member has converted, particularly in the case of conversion to Islam. This is because there are religious boundaries and religious obligations that seem strange from the beliefs and practices of the family. However, the experience of daily interaction in form of interface and the practice co-existing that has been going on since childhood and lead to friendships such as village chums, neighbours, playmates, and schoolmates provides the space between people of different faith to be better acquainted, and nurtures the understanding on matters that usually produce suspicion and confusion between them.

As a conclusion, religious diversity is a reality that must be acknowledged. The varieties in religion contain claims and needs to be judged properly. A good approach would result in a good situation and vice versa. Mostly all religions of the world put religious tolerance as a good moral character and must be implemented in the life of religious people. For example, in Islamic context, the primary source which is al-Quran has analysed and explained that the religious tolerance is a demand in religion. Some of Allah's word that explains this is: 
And We have sent down to you (O Muhammad) the Book (the Quran) with the truth, confirming that the Holy Scriptures came before it, and a watcher over it. so judge between them (the Scripture) was with what Allah has sent down the (to you), and do not follow their low desires (to turn away) from what has come to you of the truth. for every nation That some of you, We have made (set) a shari'a and the way religion (which is mandatory for each) and if Allah had wished, it made you a single people (who united the religion of the one), but it may test you (in the course) what the have reported to you. Therefore, race therefore you do good (believe and do deeds of righteousness) to Allah is your return, then it will tell you what the you disagree. (al-Quran, al-Maidah 5:48 )

Apart from the Quran, religious tolerance certainly becomes additional claim on other major guidelines respectively in the case of this tolerance which has been established by the Prophet Muhammad s.a.w. in the Constitution of Medina also known as Charter of Medina. The main focus of Charter of Medina was purposely to clarify the rights of Muslims and non-Muslims living in the same country. In additions, tolerance is culture that founded the co-existence of pluralistic society in Malaysia. The culture of tolerance can only be built if ethnical tolerance and religious tolerance is accepted as a common practice - Muslims and non-Muslims alike.

\section{References}

Al-Quran.

Abdel-Haleem Muhammad. 2009. The Politics of peace in Islam. in. Hogan, Linda \& Lehrke, Dylan Lee. (eds.). Religions and the politics of peace and conflict. Eugene Oregon: Pickwick Publications.

Abdul Halim Ramli. 2008. www.abdulhalimramli.blogspot.com [12 March 2013].

Abu Hassan Othman. 2005. Hubungan harmoni antara kaum kunci kestabilan negara. in. Islam sebagai sebuah negara Islam. Kuala Lumpur: Institut Kefahaman Islam Malaysia.

Agius \& Ambrosewicz, J. 2003. Towards a culture of tolerance and peace. Canada: International Bureau for Children's Rights.

Chandra Muzaffar. 2010. A Plea for empathy: the quest for Malaysian unity. Kuala Lumpur: Zubedy Ideahouse Sdn. Bhd.

Enizahura Abdul Aziz. 2012. Research Offier, Pusat Kajian Syariah Undang-Undang dan Politik (SYARAK), Institut Kefahaman Islam Malaysia (IKIM) and Committee JKMPKA. Interview on 22 October 2012.

Farahwahida Mohd Yusof, Aminuddin Ruskam, Azmi Shah Suratman, Mohd Nasir Ripin , Nur Raihan Nordin dan Harifah Munirah Timmiati. 2008. Kaedah penyelesaian dalam menangani kes petukaran agama dalam kalangan masyarakat Melayu-Islam di Johor, Selangor dan Wilayah Persekutuan Kuala Lumpur. http://eprints.utm.my/7864/1/ 78097.pdf.

Hassan Mat Nor. 2007. Agama dan hubungkaitnya dengan toleransi Etnik di Sabah'. in. S. Osman (ed), Toleransi Etnik dan Perpaduan Sosial. Laporan Akhir Penyelidikan IRPA. (unpublished).

Ibrahim Che Noh. 2001. Pembentukan perpaduan masyarakat Malaysia melalui Piagam Madinah dan al-Quran dan Sunah. Thesis of Doctoral Philosophy of Islamic Studies. Department of Al-Quran and Sunnah Studies, Faculty of Islamic Studies, Universiti Kebangsaan Malaysia.

Jaffary Awang. 2003. Toleransi agama dan perpaduan kaum, pandangan intelek: satu observasi ringkas. dlm. Agama dan perpaduan kaum di Malaysia. Selangor: Penerbit Universiti Kebangsaan Malaysia.

Jayaram, V. t.th. Hinduism and religion tolerance. http://www.hinduwebsite.com/hinduism/h_ tolerance.asp [27 July 2012].

Khadijah Mohd Khambali @ Hambali \& Mohd Herzali Mohd Haled. 2008. Toleransi beragama dan amalannya di Malaysia: rujukan kepada Artikel 11 Perlembagaan Persekutuan Malaysia. Jurnal Usuluddin, 27, pp. 81-92. 
Khadijah Mohd Khambali @ Hambali. 2008. Islam agama rahmah dan toleransi beragama: realiti dan cabaran. in. Khadijah Mohd Khambali @ Hambali, Mohammad Kamil Hj Abdul Majid \& Syed Mohd Hilmi Syed Abdul Rahman. (eds). Isu dan cabaran hubungan antara agama di Malaysia. Kuala Lumpur: Universiti Malaya.

Mat Zin Mat Kib. 2003. Kristian di Sabah 1881-1994. Bangi: Penerbit Universiti Kebangsaan Malaysia.

Menski, W. 2007. Hinduism in Morgan. P \& Lawton, C.A. (ed). Ethical issues in six religious traditions. ed.2. Edinburgh: Edinburgh University Press Ltd.

Mohamad Zaidi Abdul Rahman. 2007. Asas toleransi terhadap kebebasan beragama dari perspektif Islam. in. Wan Suhaimi Wan Abdullah \& Mohd Fauzi Hamat. (eds.). Konsep asas Islam dan hubungan antara agama. Kuala Lumpur: Universiti Malaya.

Sabihah Osman. 2007. Toleransi etnik dan perpaduan sosial. Laporan Akhir Penyelidikan IRPA. (unpublished).

Sahib, Hikmatullah Babu. 2008. Islam and tolerance. Kuala Lumpur: International Islamic University Malaysia.

Singh, I. J. 2003. Tolerance in religion: how Sikhism views other religions. http://www.sikhreview.org/pdf/december2003/pdf-files/pers1.pdf $\quad[2 \quad$ December 2012].

Tamring, B. A. M. 2008a. Toleransi etnik Bajau dan Kadazandusun di Sabah'. in. S. N. Mahali \& B. A. Mohd. (eds.). Pluraliti dalam Kearifan Lokal di Sabah. Kota Kinabalu: Penerbit Universiti Malaysia Sabah, Kota Kinabalu.

Tamring, B.A.M. 2008b. Toleransi etnik di Sabah: perspektif jarak sosial Bogardus. in. S. N. Mahali \& B. A. Mohd. (eds.). Pluraliti dalam kearifan lokal di Sabah. Kota Kinabalu: Penerbit Universiti Malaysia Sabah.

The Holy Bibble. n.d. Selangor: Penerbitan Buku Kristian.

Yong. 2012. Ahli Jawatankuasa Mempromosikan Keharmonian antara Penganut Agama Malaysia, (JKMPKA). Temubual pada 2 July 2012.

Zuliza Mohd Kusrin. 1999. Kebebasan beragama dan implikasinya terhadap pemelukan Islam. Disertation Master of Islamic Studies, Department of Shariah, Faculty of Islamic Studies, National University Malaysia. Unpublished Document. 